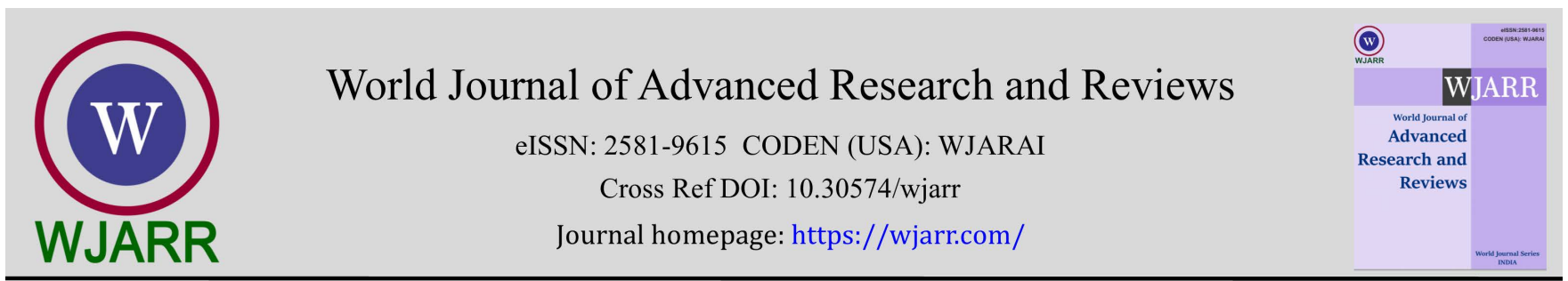

(RESEARCH ARTiClE)

\title{
Analysis of Gender Participation in Fish Production Value Chain in Akpabuyo, Cross River State Nigeria
}

\author{
Friday Ogar Idiku ${ }^{1,}{ }^{*}$, Oliver Effiong Ntui ${ }^{2}$, Dorathy Aje Iyamah ${ }^{1}$ and Dorcas Okaja Ochang ${ }^{1}$ \\ ${ }^{1}$ Department of Agricultural Extension \& Rural Sociology, University of Calabar Calabar-Nigeria. \\ 2 Department of Agricultural Education, Cross River State College of Education, Akamkpa-Nigeria.
}

World Journal of Advanced Research and Reviews, 2022, 13(02), 131-135

Publication history: Received on 28 December 2021; revised on 06 February 2022; accepted on 08 February 2022

Article DOI: https://doi.org/10.30574/wjarr.2022.13.2.0113

\begin{abstract}
The importance of fish in the diet of any human cannot be over-emphasized. The aim of this paper was to assess gender participation in fish production chain by specifically examining the socio-economic characteristics of respondents, fish product chain and value addition and gender participation in the different fish product chain as well as the challenges they face. The study was conducted in Akpabuyo Local Government Area of Cross River State, Nigeria A simple random sampling technique was used to select one hundred (100) women fish farmers for the study and questionnaire administered while data obtained were analyzed using simple frequency and percentages. The result showed that male (55\%) participated in fish production chain and are married 51\%, while a major fish value added activity was smoking and drying of fish using solar power was ranked 1st with the mean of 3.00. In terms of gender role, women have less access to resources and decision making ranked 1st (3.00). The implication is that gender participation may led to poverty reduction and food security enhancement among respondents and so there should be a level playing field for all gender to participate actively in fish production value chain.
\end{abstract}

Keywords: Fish; Gender; Participation; Production; Value Chain

\section{Introduction}

The Fisheries subsector is a significant source of food and livelihood for many people living in the coastal communities as it supplies animal protein necessary for growth and income. Fish are very high source of protein and have great nutrition value. Fish provides nutrients and micronutrients that are essential to cognitive and physical development, especially in children, and are an important part of a healthy diet. [1]. This is because Nigeria and Africa as a whole suffer much from insufficient intake relative to nutritional needs as well as excessive and unbalanced intake of dietary food [2]. Fish production was initially dependent on fish capturing but most of the captured fishes were used for industrial purposes and were hardly consumed by man. Fish production or farming is a form of aquaculture in which fishes are raised in enclosure such as fish pond, to be sold as food for human consumption [3]. Aquaculture is the fastest growing sector of food producing sector in the world [4]. It generates significant employment opportunities at multiple scales, men and women are not necessarily able to participate in aquaculture value chain in the same way, and benefits may not be evenly distributed between them. Fisheries have indeed contributed to the socioeconomic development of Nigeria and thus, information can help Fisherfolks a lot, as new information are released across the sector, from commercialization and capture or culture to processing as well as resource assessment [5]. In recognition of these gendered differences, recent literature suggest that involving a gender perspective in the production chain analysis and intervention is vital including assessment of power structure division of labor, welfare effects and empowerment [6].

\footnotetext{
${ }^{*}$ Corresponding author: Friday Ogar Idiku

Department of Agricultural Extension \& Rural Sociology University of Calabar Calabar-Nigeria.

Copyright (C) 2022 Author(s) retain the copyright of this article. This article is published under the terms of the Creative Commons Attribution Liscense 4.0.
} 
Therefore, it has become clear that the challenges women are facing needs to be addressed and evaluated at their various levels because artisanal fisher folks (women) are regarded as the backbone of aquaculture. According to Idiku (2019) women generally have been in the forefront of the fight against food crisis in the entire world. In Africa and Nigeria in particular, women produce about 78 percent of the continent's food, vegetables including meat from livestock on subsistence and small land holdings with very limited access to training and other production resources [7]. The engagement of women is particularly in coastal communities as women represent almost 50\% of the total workforce engaged in fisheries around the world though have been generally overlooked in marine conservation and fisheries management in developing countries [8].

According to [9] women are the backbones of agricultural labor force producing $40 \%$ of the gross domestic product (GDP) and over $50 \%$ of food in developing nations. A fish production chain considers the entire stakeholder that intervenes and interacts in fish production and consumption (Michigan State University [10]. In spite of the challenges, rural women are engaged in a wide range of farming activities and are responsible in most cases for food production, processing, distribution, home consumption and for sale [7]. Aquaculture value chain links the movement of fish products from the farmers to the consumers including input supplies, production, processing, marketing and finance. Information and communication Technologies or new media are necessary conditions for improvement of all areas of agriculture with adequate quality information. In other words, with the rapid development of information and communication technologies (ICTs), data and information can be effectively generated, stored, analyzed, disseminated and used to support farmers and farming communities to improve agricultural productivity and sustainability especially among women Fisherfolks [11]. However, there is a complexity in the nature of fish value chain in terms of unorganized marketing system, fish movement from farmer (producer) through processors (who can also be farmers, middlemen or processors) to middlemen (fish traders, wholesalers/retailers). Social norm and power relation shape and limit women adoption and use of aquaculture knowledge, technologies and practices through extension [12]. Sex disaggregated data in fish production are still scanty and there is a near or total absence of women in intermediate and high leading positions in the seafood industry [13]. Even when performing the same tasks in the same node, women are often and but always paid less than their male counterparts. It is against this background that this study intends to assess gender participation in fish production chain by specifically examining the socio-economic characteristics of respondents, fish product chain and value addition and gender participation in the different fish product chain as well as the challenges they face.

\section{Material and methods}

The study was conducted in Akpabuyo Local Government Area of Cross River State, Nigeria. The area has a population of 360,000 people and is located in the Southern Senatorial District with headquarters at Ikot Nakanda. It consists of ten (10) Council Wards with the major ethnic groups as Efiks, Quas and Efuts. The area lies between Latitude $4^{\circ} 5^{\prime}$ and $5^{\circ} 40^{\prime}$ and Longitude $8^{\circ} 25^{\prime}$ and $8^{\circ} 32$ East of the meridian. A simple random sampling technique was used to select one hundred (100) women fish farmers for the study area and questionnaire administered while data obtained were analyzed using simple frequency and percentage.

\section{Results and discussion}

Table 1 Distribution of respondents according to socioeconomic characteristics

\begin{tabular}{|c|c|c|}
\hline Variables & Frequency & Percentage \\
\hline \multicolumn{3}{|l|}{ Sex } \\
\hline Male & 55 & 55.0 \\
\hline Female & 45 & 45.0 \\
\hline \multicolumn{3}{|l|}{ Age (years) } \\
\hline $20-40$ & 34 & 34.0 \\
\hline $41-60$ & 46 & 46.0 \\
\hline 61 and above & 20 & 20.0 \\
\hline \multicolumn{3}{|l|}{ Marital status } \\
\hline Single & 30 & 30.0 \\
\hline Married & 51 & 51.0 \\
\hline
\end{tabular}




\begin{tabular}{|l|c|c|}
\hline Divorced & 12 & 12.0 \\
\hline Widowed & 7 & 7.0 \\
\hline Educational level \\
\hline No formal education & 27 & 27.0 \\
\hline Primary & 31 & 31.0 \\
\hline Secondary & 40 & 40.0 \\
\hline Tertiary & 2 & 2.0 \\
\hline Household size & 17 & 17.0 \\
\hline $1-5$ & 47 & 47.0 \\
\hline $6-10$ & 36 & 36.0 \\
\hline 11 and above & 43 & 43.0 \\
\hline Number of fish caught & 34.0 \\
\hline $1-20$ & 34 & 23.0 \\
\hline $21-40$ & 23 & \\
\hline 41 and above & 18 & 18.0 \\
\hline Farming (years) & 24 & \\
\hline $1-5$ & 58 & \\
\hline $6-10$ & & \\
\hline 11 and above & & \\
\hline \multicolumn{2}{|c|}{ Source: Field survey, 2021 } \\
\hline
\end{tabular}

Socioeconomic characteristics of the fish farmers are presented Table 1 and the result showed that male (55\%) participated in fish production chain while female were (45\%). This implies that on the average, the proportion of men engaged in fish farming activities in the study area are marginally higher than female. This result agreed with the report of [14] that the male fisher folks dominate in fish harvesting activities more than their female counterpart. Similarly,

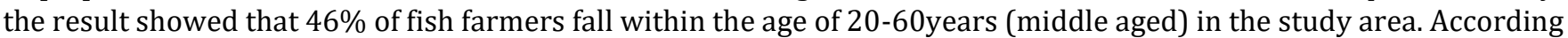
to [15] fish farmers within this categorization are likely to adopt improved technologies that have been proven or have the potential to lead to increased income and improved productivity. In terms of marital status, 51\% are married whereas $41 \%$ attained secondary school and household size of 6-10 was $47 \%$.

Table 2 Distribution of respondents by fish product chain and value addition

\begin{tabular}{|c|l|c|c|}
\hline S/N & \multicolumn{1}{|c|}{ Fish product and value addition } & Mean & Rank \\
\hline 1 & Cleaning of fish and packing them into containers & 2.80 & $3^{\text {rd }}$ \\
\hline 2 & Preserving the fish using cold room & 2.90 & $2^{\text {nd }}$ \\
\hline 3 & Smoking and drying the fish using solar power & 3.00 & $1^{\text {st }}$ \\
\hline 4 & Microwave heating & 2.50 & $4^{\text {th }}$ \\
\hline 5 & Common processing techniques : salting, sun drying and frying to improve the flavour & 2.40 & $5^{\text {th }}$ \\
\hline \multicolumn{2}{|c}{ Source: Field survey, 2021 }
\end{tabular}

Table 2 shows that smoking and drying the fish using solar power was ranked 1st with the mean of 3.00, preserving the fish using cold room was ranked 2 nd with the mean of 2.90 and cleaning of fish and packing them into containers was ranked 3rd. This implies that majority of respondents participate in smoking and drying of fish using solar power and preserving the fish using cold room. Other value addition products have been documented, such as fish cakes and fish cake burgers made from shrimp by-catch, and developed by fishers as an entrepreneurial endeavor.

Table 3 result shows the various roles carried out by the respondents, that women have less access to resources and decision making was ranked 1 st (3.00), women play greater role in post-harvest than in catching was ranked $2^{\text {nd }}(2.80)$ while men involve in making and mending nets, baskets, and pot baiting hooks and providing services to the fishing boat was ranked 3rd (2.60). This result indicates that the males are more involved in the laborious activities when compared with the female aquaculturists. This might be due to the fact that the female gender does not have the required 
physical strength to engage in such activities confirming the findings of [16]. This implies that women lack opportunities to hold managerial and decision making posts. According to [17] wives of the fishermen buy fish from their husbands and smoke them before taking them to markets.

Table 3 Distribution of respondents by gender participation in fish production value chain

\begin{tabular}{|c|l|c|c|}
\hline S/N & \multicolumn{1}{|c|}{ Gender participation in fish production chain } & Mean & Rank \\
\hline 1 & Women have less access to resources and decision making & 3.00 & $1^{\text {st }}$ \\
\hline 2 & Women play greater role in post-harvest than in catching & 2.80 & $2^{\text {nd }}$ \\
\hline 3 & $\begin{array}{l}\text { Men go on fishing ground which are far from the house/more distance water while women } \\
\text { use small boat and gear to fish in fishing ground nearer to the house }\end{array}$ & 2.50 & $4^{\text {th }}$ \\
\hline 4 & $\begin{array}{l}\text { Men involve in making and mending nets, baskets and pots baiting hooks and providing } \\
\text { services to the fishing boats }\end{array}$ & 2.60 & $3^{\text {rd }}$ \\
\hline
\end{tabular}

Source: Field survey, 2021

Table 4 Distribution of respondents by challenges of gender participation in fish production chain

\begin{tabular}{|c|c|c|c|}
\hline $\mathbf{S} / \mathbf{N}$ & Challenges of gender participation in fish production value chain & Mean & Rank \\
\hline 1 & Lack of skills and technical know-how in adding value to fish & 3.00 & $2^{\text {nd }}$ \\
\hline 2 & $\begin{array}{l}\text { Fishing communities have minimal facilities for child and healthcare, education and } \\
\text { entertainment }\end{array}$ & 2.70 & $3^{\text {rd }}$ \\
\hline 3 & Inadequate storage and processing facilities & 3.90 & $1^{\text {st }}$ \\
\hline 4 & Limited access to modern technology & 2.50 & $5^{\text {th }}$ \\
\hline 5 & Poor marketing arrangements & 2.60 & $4^{\text {th }}$ \\
\hline 6 & Lack of encouragement from government & 2.00 & $6^{\text {th }}$ \\
\hline 7 & Lack of access to market and rural infrastructure & 3.00 & $2^{\text {nd }}$ \\
\hline 8 & Challenges of diseases, poverty and ignorance & 2.50 & $5^{\text {th }}$ \\
\hline
\end{tabular}

Source: Field survey, 2021

Table 4 shows the challenges faced by respondents in the study area, irrespective of their gender, inadequate storage and processing facilities is ranked 1st with mean (3.90), Lack of skills and technical know-how in adding value to fish and lack of access to market and rural infrastructure are ranked 2nd with mean of (3.00), fishing communities have minimal facilities for child and health care, education and entertainments are ranked 3rd with mean(2.70), poor marketing arrangement are ranked 4th with mean (2.60), limited access to modern technology and challenges of diseases, poverty and ignorance are ranked 5th with mean (2.50), and lack of encouragement from government is ranked 6th with mean (2.00). This implies that any mean above 2.5 is seen as a challenge to them, and any mean below or equal to 2.5 is not a challenge to the fish farmers. So therefore, lack of skills and technical know-how in adding value to fish and lack of access to market and rural infrastructure (3.00) are major challenges faced by respondents in the study area. While fishing communities have minimal facilities for child and health care, education and entertainments are also seen as challenge affecting them. Then lack of encouragement from government, diseases, poverty and ignorance, and limited access to modern technology (2.50 and 2.00) it shows that it's not a challenge to them. It was also observed that cultural norms did not affect the male.This result confirm the findings of [7] that rural women are engaged in a wide range of farming activities and are responsible in most cases for food production, processing, distribution, home consumption and for all.

\section{Conclusion}

This study concluded that females are mostly engaged in processing while the males are more into fish production and that gender participation has led to poverty reduction and food security enhancement. There should be a level playing field for all gender to participate actively in fish value chain.

\section{Compliance with ethical standards}

\section{Acknowledgments}

All authors are acknowledged for their contributions. 


\section{Funding}

No funding was received for this study.

\section{Disclosure of conflict of interest}

There is no conflict of interest to declare.

\section{Statement of informed consent}

Informed consent was obtained from all individuals that participated even before questionnaire was administered to elicit information for this study.

\section{References}

[1] Devadasan K. Value added fish and fishery products. Fishing Chimes.2003; 23(1): 131-136.

[2] Idiku F O, Elemi GF. Effective Nutrition Education for Behavioural and Policy Change among Rural Households in Nigeria. Annals of Nutrition and Metabolism. 2015; 67(1): 506.

[3] Food and Agriculture Organization (FAO). The State of World Fisheries and Aquaculture (2014): Opportunities and Challenges FAO, Rome. 2014; 223.

[4] Subasinghe R, Subasinghe D, Soto J,Jia J. Global aquaculture and its role in sustainable development Review Aquaculture. 2009; 1(1): 2-9.

[5] Idiku FO. Ogbonna KI, Ogar PO,David GM. Weather Information Needs of Displaced Artisanal Fishermen in BakassiPennisula Nigeria. Library Philosophy and Practice (e-journal).2020; 4134.

[6] Schumacher KP. Gender relations in global agri-food value chains: a review. 2014; 28.

[7] Idiku F O. Training Needs of Women Vegetable Farmers in the University of Calabar Farm, Nigeria. Direct Research Journal of Agriculture and Food Science (DRJAFS). 2019; 7(6): 137-140.

[8] United States Agency for International Development (USAID). Gender and Pro-poor Value Chain Analysis: Insights from the GATE Project Methodology and Case Studies Washington D.C, USAID. 2009.

[9] Ani AO, Ogunnilka SS, Ifah.Relationship between socio-economic characteristic of rural women farmers and their adoption of farm technologies in Southern Ebonyi State, Nigeria. International Journal of Agricultural and Biology.2004; 6(5): 802-805.

[10] Michigan State University. Fish farming-value chain in image. 21 March 2018.

[11] Idiku FO, Eta HC, Elemi GF. 2021. Utilization of New Media for Agricultural Information by Farmers in SouthSouth Nigeria. Library Philosophy and Practice (e-journal). 6449.

[12] Morgan M, Terry S, Rajaratnam J. Socio-cultural dynamics shaping the potential of aquaculture to deliver development outcomes Rev. Aquaculture. 2016.

[13] Monfort MC. The Role of Women in the Seafood Industry. GLOBEFISH Research Programme, 119 Food and Agriculture organisation, Rome. 2015; 67.

[14] Omitoyin SA, Tosan FB. Potential impacts of climate change on livelihood and food security of artisanal fisher folks in Lagos State, Nigeria. Journal of Agricultural Science. 2012; 4(9): 20 - 30.

[15] Ande CE.Essential Economics for senior secondary schools (2nd edition) Ogun State, Nigeria: TONAD Publishers Limited.2008; 157.

[16] Nwabueze AA. The Role of Women in Sustainable Aquaculture Development in Delta State. Journal of Sustainable Development in Africa.2010; 12(5): 284-293.

[17] Odutale DO, George FOA,Idowu AA. Role of women in fisheries in coastal wetland areas of Journal of Biology, Agriculture and Healthcarewww.iiste.org ISSN 2224-3208 (Online). 2011; 7(16): 1. 